\title{
Study on Hexavalent Chromium Reduction by Chromium Resistant Bacterial Isolates of Sukinda Mining Area
}

\author{
V. Mishra, D.P. Samantaray, S.K. Dash, B.B. Mishra, R.K. Swain \\ Post Graduate Department of Microbiology, Department of Animal Nutrition, Orissa University of Agriculture \\ and Technology, Bhubaneswar-751003, Orissa, India \\ E-mail:dpsamantaray@yahoo.com
}

Received: 10.05.2010, Accepted: 17.09.2010

\begin{abstract}
Rapid industrialization coupled with explosive development of chemical and mining industries has not only resulted in global deterioration of the environmental quality but also has drawn attention of scientists for an effective measure to control environmental pollution. Sukinda in the district of Jajpur, Orissa has drawn worldwide attention as one of the most polluted area with chromium due to chromate rich. In the present experiment, attempt has made to detoxify $\mathrm{Cr}$ (VI) by chromium resistant bacterial isolates of Sukinda mining area. Random soil and water samples were collected aseptically from four different sites of the mining area and physiochemical parameters of the samples were estimated. Out of the twelve, four chromium resistant bacterial isolates viz., Micrococcus luteus, Pseudomonas putida, Serratia marcescens and Acinetobacter calcoaceticus tolerated hexavalent chromium beyond $500 \mathrm{ppm}$ and selected for reduction. Among all, Acinetobacter calcoaceticus shown highest amount of hexavalent chromium reduction of $67.14 \%$ incubated at $30^{\circ} \mathrm{C}$ for $24 \mathrm{hr}$ at $\mathrm{pH}$ 7. Then Acinetobacter calcoaceticus was selected for parametric studies and observed to exhibit highest reduction i.e., $70.53 \%$ potential at $\mathrm{pH} 8.0$, temperature $30^{\circ} \mathrm{C} / 24 \mathrm{hr}$. Therefore, Acinetobacter calcoaceticus may be use in the bioremediation of hexavalent chromium toxicity.
\end{abstract}

Key words: Bioremed iation, hexavalent chromium, deterioration

\section{Introduction}

Sukinda valley of Jajpur district, the fourth most polluted place in the world (Blacksmith institute report, 2007) accounts 97\% of India's chromites ore deposits. Intensive open cast mining for the last more than 70 years generated 30 million tones of hexavalent chromium wastes polluting soil, water, ruined agricultural fields and slowly poisoning the local flora and fauna including 2.6 million human population of the state. The environment is sensitive to metals due to their longevity and toxicity (Aravindhan et al., 2007). Chromium, an essential micronutrient in animal physiology required for normal carbohydrate and lipid metabolism (Anderson, 1989) and also a priority pollutant is well known for the mutagenicity (Petrilli and Flora, 1977), carcinogenicity (Gruber and Jennette, 1978) and teratogenicity (Gale, 1978) of its hexavalent form in humans, experimental animals (IARC, 1990) and plants (Flora et 
al., 1990). $\mathrm{Cr}$ (VI) is water-soluble, bioleachable form that can intracellularly reduced to $\mathrm{Cr}(\mathrm{V})$ and reacts with nucleic acids and other cell components to produce mutagenic and carcinogenic effects on biological systems (McLean and Beveridge, 2001). Conventional chemical treatment of $\mathrm{Cr}$ (VI) generated large volume of sludge, dangerous gases and expensive cost of the chemical. Reducing agents makes it imperative to look into safer and cheaper alternatives, where the metal resistant (Kasan and Baecker, 1989) microbial communities are of primary importance in bioremediation of metal contaminated sites and represent a substantial proportion of the in situ biomass and metabolic diversity. Bioreduction of $\mathrm{Cr}$ (VI) occurs directly due to microbial metabolism or indirectly by bacterial metabolites (Losi et al., 1994). Many scientists have investigated and demonstrated the feasibility of using biological processes for the treatment of $\mathrm{Cr}$ (VI) contaminated sites and industrial effluents by either pure culture or consortium of $\mathrm{Cr}$ (VI) reducing bacteria (Camargo et al., 2003; Aravindhan et al., 2007; Rahman et al., 2007). Cr (VI) reduction by locally isolated strains and optimization of factors involved in Cr (VI) reduction carried out by monoculture of isolated bacteria to investigate its efficiency as an efficient tool for bioremediation of chromium-contaminated sites.

\section{Methodology}

\section{Sample collection}

Four different sites viz., Kalarangi mines, South Kaliapani mines, Kamardha mines and Dumsala canal were selected in the Sukinda mining area of district Jajpur,
Orissa, located between $20^{\circ} 53^{\prime} \mathrm{N}-21^{\circ} 05^{\prime} \mathrm{N}$ and $85^{\circ} 40^{\prime} \mathrm{E}-85^{\circ} 53^{\prime} \mathrm{E}$. Representative water samples were collected aseptically in sealed, sterile $500 \mathrm{ml}$ containers from different sites. Soil and sediment samples were collected in sterile plastic bags from a depth of 5 inch below the surface and from the surface respectively during the month of February 2008 following the methods of (Zobell, 1946). Samples then transported aseptically and processed immediately in the laboratory for physico-chemical parameters analysis.

\section{Physico-chemical parameters analysis}

Physico-chemical parameter like temperature, $\mathrm{pH}$, moisture content, total chromium and hexavalent chromium content were analyzed by using (Okatone) digital thermometer, (Systronics 361) $\mathrm{pH}$ meter, and oven drying method respectively. Hexavalent chromium content of the water samples was analyzed by 1, 5Diphenylcarbazide (DPC) method (APHA, 1992) and the total chromium content was analyzed by acid digestion followed by (DPC) assay. The hexavalent chromium content of the soil and sediment samples were estimated by alkaline digestion followed by DPC assay and their total chromium content was analyzed by acid digestion followed by DPC assay (LATS, 2003).

\section{Bacteriological analysis of sample}

Luria Bertani broth, agar and phosphate buffer solution were used for microbial isolation and hexavalent chromium reduction studies procured from HiMedia Laboratories, Mumbai. Isolation of Chromium resistant bacteria was done by 
enrichment culture technique, using Potassium dichromate as hexavalent chromium supplement in Luria Bertani broth, samples were inoculated into the broth, incubated at $30^{\circ} \mathrm{C}$ overnight and were streaked onto Luria Bertani agar (LA) plates which were further incubated for $24 \mathrm{hr}$. The pure cultures of isolated strains were preserved in LA slants in vials under refrigerated $\left(4^{\circ} \mathrm{C}\right)$ conditions and coded as CRB1 to CRB12 for further uses. The Gram-negative isolates were identified by standard biochemical tests (Collins and Lyne, 1970; Hansen and Sorheim, 1991) as per the requirements of bacterial identification software PIBWin (Byrant, 2004) and Bergey's manual of determinative bacteriology. Gram-positive isolates were identified by Api Staph strips (Biomeriux, France).

Estimation of heavy metal tolerance of bacterial isolates

For estimation of chromium tolerance molten LA medium was supplemented with $\mathrm{Cr}$ (VI) with final concentration ranging from $100-1100 \mathrm{mg} / \mathrm{l}$ by using filter $(0.22$ $\mu \mathrm{m})$ sterilized $\mathrm{K}_{2} \mathrm{Cr}_{2} \mathrm{O}_{7}$ solution. The isolates were streaked onto the LA plates and incubated at $30^{\circ} \mathrm{C}$ for $48 \mathrm{hr}$ and the resistance pattern or minimum inhibitory concentration (MIC) was noted down. Of these, four isolates were selected for further reduction studies basing on their chromium tolerance. Similarly metal tolerance study was also carried by varying the concentration (100-1000 ppm) of each heavy metals like $\mathrm{Fe}^{2+}, \mathrm{Cu}^{2+}, \mathrm{Ni}^{2+}, \mathrm{Hg}^{2+}$ and $\mathrm{Co}^{2+}$.

\begin{abstract}
Estimation $\mathrm{pH}$ tolerance of bacterial isolates

The $\mathrm{pH}$ tolerance test was conducted to study the cardinal $\mathrm{pH}$ of the chromium resistant bacteria. Five milliliter of the medium was taken in different test tubes and the $\mathrm{pH}$ was adjusted from 3-12 with help of $1 \mathrm{~N} \mathrm{HCL}, 1 \mathrm{~N} \mathrm{NaOH} .100 \mu$ l of the overnight culture (LB) was dispensed in to the test tubes and incubated at $30^{\circ} \mathrm{C}$ for 24 hr. A loopful of overnight culture was subcultured on to LA plates and all the plates were incubated at $30^{\circ} \mathrm{C}$ for $24 \mathrm{hr}$. Then the cardinal $\mathrm{pH}$ was determined from the observation.
\end{abstract}

\section{Aerobic hexavalent chromium reduction by chromium resistant bacteria}

For preliminary reduction study, selected bacterial isolates were inoculated into $\mathrm{LB}$ with $100 \mathrm{ppm}$ of $\mathrm{Cr}(\mathrm{VI})$ and incubated at $30^{\circ} \mathrm{C}$ for $24 \mathrm{hr} / 100 \mathrm{rpm}$ with incubator shaker (STM-225-IS). Sampling was done after $24 \mathrm{hr}$ and cells were collected after centrifugation (Remi Compufuge) at 10,000 rpm for 10 minutes. Then supernatant was analyzed for residual chromium by $1,5-$ Diphenyl carbazide method by measuring absorbance at $540 \mathrm{~nm}$ using a spectrophotometer (Systronics 104). Similarly in order to observe chromium reduction in a non-nutritive medium like Phosphate buffer solution the collected cells were washed twice with PBS and resuspended in $50 \mathrm{ml}$ of PBS with $100 \mathrm{ppm}$ of $\mathrm{Cr}$ (VI) and reduction was observed following DPC method at hourly intervals up to $6 \mathrm{hr}$ and finally after $24 \mathrm{hr}$. 
Optimization of $\mathrm{pH}$ and temperature on chromium reduction

The influences of $\mathrm{pH}$ and temperature on chromium reduction were assessed with $\mathrm{LB}$ medium and culture condition described earlier for chromium reduction. For the effect of $\mathrm{pH}$, autoclaved culture medium was adjusted to $\mathrm{pH} 7$ and 8 with HCL or $\mathrm{NaOH}$ and incubated at $30^{\circ} \mathrm{C}$. Similarly keeping the optimum $\mathrm{pH}$ constant for reduction, temperature was varied viz., $20^{\circ} \mathrm{C}, \quad 30^{\circ} \mathrm{C}$ and $37^{\circ} \mathrm{C}$ and optimum temperature was observed for chromium reduction.

\section{Results \\ Physico-chemical parameters analysis}

The results of physico-chemical parameter analysis of ten different samples are presented in table 1 . The average hexavalent chromium content of the water, soil and sediments samples were $0.689 \mathrm{ppm}, 39$ $\mathrm{mg} / \mathrm{kg}, 46.74 \mathrm{mg} / \mathrm{kg}$ respectively, but the chromium content of the water samples far exceeds the prescribed EPA standards i.e., $0.05 \mathrm{ppm}$. Presence of such high levels of hexavalent chromium in the water can be attributed to careless discharge of untreated wastewater from mines, rainwater running off the overburden and dumps collapsing and mixing with water in the river, which is co-related with the research report of Black Smith institute (2007).

\section{Bacteriological analysis of sample}

Twelve bacteria were isolated of which 7 were Gram positive and 5 were gram negative. The Gram-negative isolates were Pseudomonas cepacia, Pseudomonas putida, Pseudomonas pseudomallei,
Serratia marcescens, Acenetobacter calcoaciticus, Acinetobacter lwoffii, and Moraxella urethralis. The Gram-Positive isolates were mostly cocci viz., Staphylococcus xylosus, Staphylococcus cohniicohnii, Micrococcus luteus, Kocuria varians and Bacillus sp.

Estimation of heavy metal tolerance of chromium resistant bacteria

Out of all the bacterial isolates, four isolates i.e., M. luteus (CRB6), P. putida (CRB8), $S$. marcescens (CRB9) and A. calcoaceticus (CRB10) could tolerate Cr (VI) chromium up to 500, 600, 900 and $1000 \mathrm{ppm}$ respectively. Similar results have been found by most of the researcher (Srinath et al., 2001; Camargo et al., 2003; Rahman et al., 2007) while working on Cr (VI) chromium reduction by different bacterial isolates. Natural habitats are generally characterized by the co-existence of a large number of toxic and non-toxic cations and therefore, it is necessary to study multiple metal effects on the physiology and biochemistry of microorganisms (Verma and Singh, 1995). A. calcoaceticus showed a broad range of tolerance to heavy metals like $\mathrm{Fe}^{2+}, \mathrm{Cu}^{2+}, \mathrm{Ni}^{2+}, \mathrm{Hg}^{2+}$ and $\mathrm{Co}^{2+}$ up to concentration of 1000, 900,1000, 100 and $300 \mathrm{ppm}$ respectively. Apart from all the metals, the highest tolerance was observed towards $\mathrm{Fe}^{2+}$ and $\mathrm{Ni}^{2+}$. These observations assume great significance because effluents from any metal related to industry have several metal ions or contaminants. Tolerance to other metals has an added advantage of withstanding the presence of other metal ions while performing the desired activity. 
Estimation of pH tolerance of chromium resistant bacteria

The $\mathrm{pH}$ tolerance profile reveals that the optimum $\mathrm{pH}$ for most of the isolates ranges 7-9. All isolates except $P$. putida could tolerate a $\mathrm{pH}$ range of 4-12. Alkaline $\mathrm{pH}$ favours the growth of most of the isolates than acidic $\mathrm{pH}$. This result corresponds to that of Camargo et al. (2003), who observed that isolates more tolerant to $\mathrm{Cr}$ (VI) grew better at $\mathrm{pH}$ 7-9. This might be a result of adaptation of the isolates to the natural habitat, which was mostly alkaline.

\section{Aerobic hexavalent chromium reduction by chromium resistant bacteria}

Hexavalent chromium reduction is dependent upon $\mathrm{pH}$, temperature and $\mathrm{Cr}$ (VI) concentration. The twenty-four hours hexavalent chromium reduction result (Fig. 1) in a nutritive media (LB) reveals that out of all the four isolates, A. calcoaceticus reduced $\mathrm{Cr}$ (VI) by $67.14 \%$ at $30^{\circ} \mathrm{C} / 24$ $\mathrm{hr} / \mathrm{pH}$ 7. Percentage of hexavalent chromium reduction by isolates $S$. marcescens, $M$. luteus, $P$. putida were $65.02,53.14$ and $50.72 \%$ respectively. Signs of chromate reduction like change in color of medium from yellow to greenish along with production of off-white residues were observed, the results were in accordance with Faisal and Shahida (2004) and Aravindhan et al. (2007). An interesting result was obtained by Zakaria et al. (2007) that Acinetobacter haemolyticus reduces $\mathrm{Cr}$ (VI) upto $100 \mathrm{mg} / \mathrm{l}$ but the rate of reduction was increased with $\mathrm{Cr}$ (VI) concentration i.e., upto30 $\mathrm{mg} / \mathrm{l}$. TEM studies showed that higher $\mathrm{Cr}$ (VI) concentration affects the shape and size of bacteria. The presence of electron dense particles in the cytoplasmic region of the organism suggested deposition of $\mathrm{Cr}$ (VI) in the cells. Optimum temperature and $\mathrm{pH}$ for $\mathrm{Cr}(\mathrm{VI})$ reduction has been reported to be $30^{\circ} \mathrm{C}$ and $7-7.8$ by Losi et al. (1994) and Camargo et al. (2003), $\quad 30^{\circ} \mathrm{C}$ being the normal environmental temperature and $\mathrm{pH} 7$ being the optimum $\mathrm{pH}$ for growth, these conditions were selected for the preliminary reduction studies.

However, the results of the hourly hexavalent chromium reduction by the selected bacterial isolates in PBS (Fig. 2) indicates that rate of reduction is directly proportional to time. Acinetobacter calcoaceticus reduced $20-28.5 \%$ of $\mathrm{Cr}$ (VI) within $3 \mathrm{hr}$, after that the rate was almost constant i.e., ranged 34.03 to $38 \%$. This difference in trend of reduction in a nonnutritive medium (PBS) may be due to decrease in physiological and metabolic activities of the isolates (Losi et al., 1994; Camargo et al., 2003) and viability after some time and possible inhibition of biomass activity by prolonged chromate toxicity in a non-nutritive medium. This study indicates that the rate hexavalent chromium reduction is higher in nutritive medium (LB) than in non-nutritive medium. Therefore, optimization of $\mathrm{pH}$ and temperature for hexavalent chromium reduction has been conducted in a nutritive medium.

\section{Optimization of $\mathrm{pH}$ and temperature on chromium reduction}

It has been observed from the chromium reduction profile of all the four selected bacterial isolates, A. calcoaceticus reduced highest quantity of $\mathrm{Cr}$ (VI) in LB medium and selected for parametric study. It could 
V. Mishra, D.P. Samantaray, S.K. Dash, B.B. Mishra and R.K. Swain / Our Nature (2010) 8: 63-71

Table 1. Physico-chemical parameters of the mines sample.

\begin{tabular}{|c|c|c|c|c|c|c|c|}
\hline$\overline{\mathbf{S N}}$ & $\begin{array}{l}\text { Sampling } \\
\text { Sites } \\
\end{array}$ & $\begin{array}{l}\begin{array}{l}\text { Type of } \\
\text { sample }\end{array} \\
\end{array}$ & pH & $\begin{array}{l}\text { Temp. } \\
\left({ }^{\circ} \mathrm{C}\right) \\
\end{array}$ & $\begin{array}{l}\begin{array}{l}\text { Moisture } \\
(\%)\end{array} \\
\end{array}$ & $\begin{array}{l}\text { Total } \mathrm{Cr} \\
\text { content }\end{array}$ & $\begin{array}{l}\mathrm{Cr}(\mathrm{VI}) \\
\text { content } \\
\end{array}$ \\
\hline \multirow{3}{*}{1.} & \multirow{3}{*}{$\begin{array}{l}\text { Kalarangi } \\
\text { mines }\end{array}$} & Water & 8.01 & 24 & - & $0.277 \mathrm{mg} / \mathrm{l}$ & $0.192 \mathrm{mg} / 1$ \\
\hline & & Soil & 7.67 & ND & 2.59 & $5480 \mathrm{mg} / \mathrm{kg}$ & $66 \mathrm{mg} / \mathrm{kg}$ \\
\hline & & Sediment & 6.82 & ND & 27.2 & $5950 \mathrm{mg} / \mathrm{kg}$ & $7.35 \mathrm{mg} / \mathrm{kg}$ \\
\hline \multirow{2}{*}{2.} & \multirow{2}{*}{$\begin{array}{l}\text { Dumsala } \\
\text { canal }\end{array}$} & Water & 8.00 & 24 & - & $0.294 \mathrm{mg} / 1$ & $0.238 \mathrm{mg} / \mathrm{l}$ \\
\hline & & Sediment & 7.62 & ND & 31.56 & $3900 \mathrm{mg} / 1$ & $66 \mathrm{mg} / \mathrm{kg}$ \\
\hline \multirow{3}{*}{3.} & \multirow{3}{*}{$\begin{array}{l}\text { South } \\
\text { kaliapani } \\
\text { mines }\end{array}$} & Water & 7.62 & 25 & . & $3.515 \mathrm{mg} / 1$ & $2.036 \mathrm{mg} / \mathrm{l}$ \\
\hline & & Soil & 9.49 & ND & 12.5 & $3000 \mathrm{mg} / \mathrm{l}$ & $12 \mathrm{mg} / \mathrm{kg}$ \\
\hline & & Slurry & 6.60 & ND & 34.22 & $7800 \mathrm{mg} / 1$ & $34 \mathrm{mg} / \mathrm{kg}$ \\
\hline \multirow{2}{*}{4.} & Kamardha & Water & 7.75 & 25 & - & $0.387 \mathrm{mg} / \mathrm{l}$ & $0.292 \mathrm{mg} / \mathrm{l}$ \\
\hline & Mines & Sediment & 7.08 & ND & 36.6 & $4900 \mathrm{mg} / \mathrm{kg}$ & $119 \mathrm{mg} / \mathrm{kg}$ \\
\hline
\end{tabular}

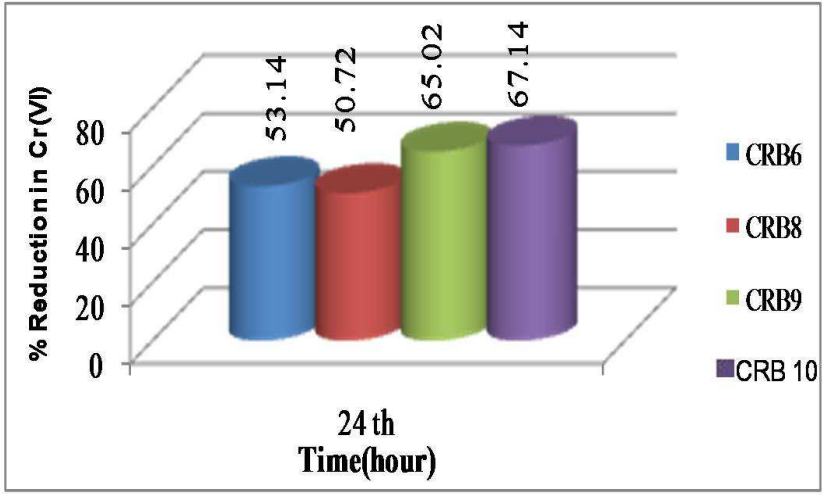

Figure 1. Hexavalent chromium reduction ( $24 \mathrm{hr}$ ) of bacterial isolates in LB.

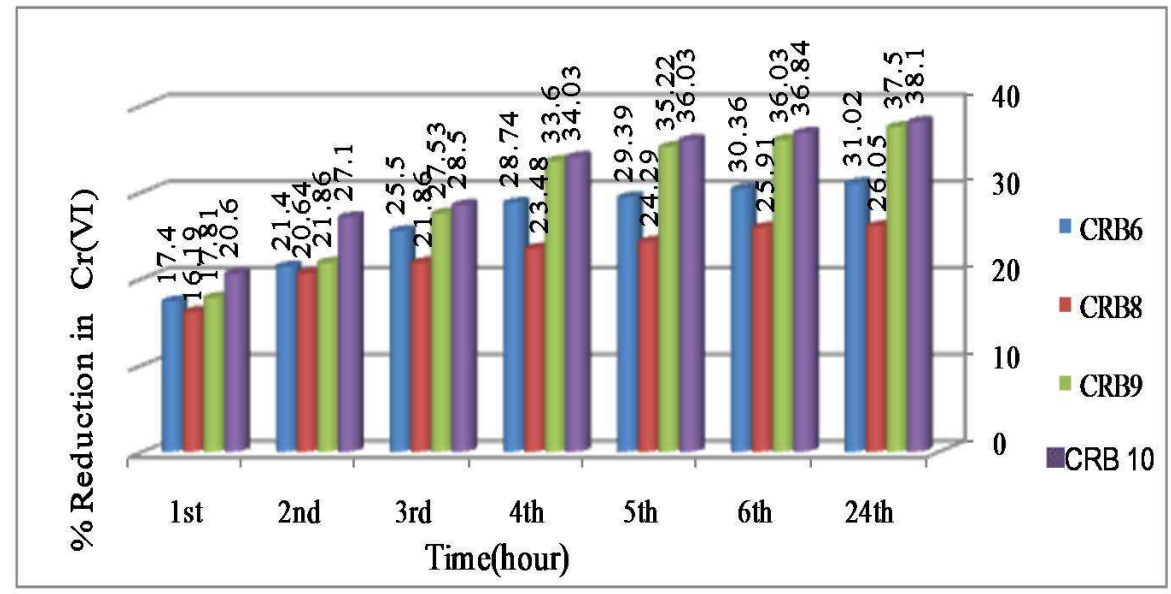

Figure 2. Hexavalent chromium reduction ( $24 \mathrm{hr}$ ) of bacterial isolates in PBS. 
reduce $70.53 \%$ of hexavalent chromium optimally at $\mathrm{pH} 8$, in LB within $24 \mathrm{hr}$ (Fig. $3)$. For most of the isolates, optimum $\mathrm{pH}$ for growth correlates with highest rate of hexavalent chromium reduction (Camargo et al., 2003). The relationship between $\mathrm{pH}$ and $\mathrm{Cr}$ (VI) reduction was not surprising because chromate is the dominant chromium species in aqueous environment at pH 6.5-9 (McLean and Beveridge, 2001). Optimum $\mathrm{pH}$ for growth of $\mathrm{Cr}$ (VI) resistant bacteria was reported at 7-7.8, but hexavalent chromium forms are soluble over a wide $\mathrm{pH}$ range and generally mobile in soil-water systems (Losi and Frankenberger, 1994).

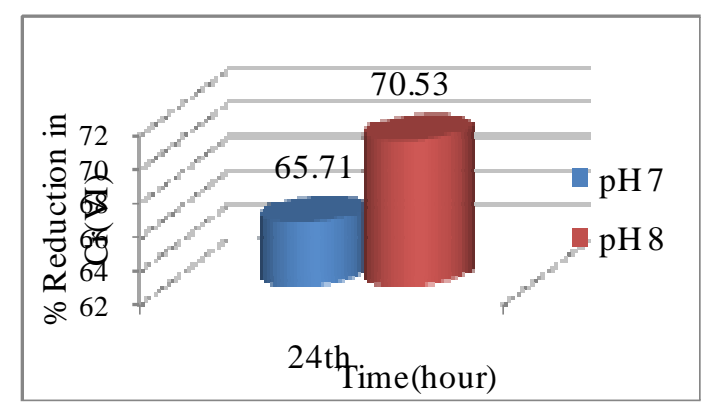

Figure 3. Hexavalent chromium reduction ( $24 \mathrm{hr}$ ) by isolate CRB 10 in $\mathrm{LB}$ at different $\mathrm{pH}$.

The hexavalent chromium reduction profile was monitored at different temperatures ranging from $20-37^{\circ} \mathrm{C}$ in $\mathrm{LB}$ for $24 \mathrm{hr}$ keeping constant the optimum $\mathrm{pH}$ at 8.0. Highest reduction $(70.53 \%)$ was observed (Fig. 4) at optimum temperature of $30^{\circ} \mathrm{C}$ and percentage of reduction decreased with increase in temperature. This is possibly because of decreased enzyme activity with increase in temperature. This could be due to loss of viability or metabolic activity of the cells on prolonged incubation at higher temperature (Aravindhan et al., 2007). Losi et al. (1994) and Camargo et al. (2003) who reported an optimum temperature of 30 to $37^{\circ} \mathrm{C}$ for chromate reduction also obtained similar results.

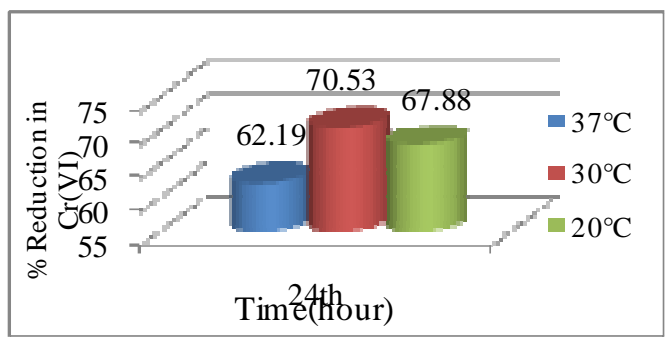

Figure 4. Hexavalent chromium reduction (24 hr) by isolate CRB $10 \mathrm{in} \mathrm{LB}$ at different temperatures.

\section{Conclusion}

The experimental observations indicate that the locally isolated strains show high $\mathrm{Cr}$ (VI) tolerance and demonstrate good metal removal capability. The advantages of selecting the indigenous bacteria from chromite mines of Sukinda for bioremedial purpose may be the minimization of inhibitory effects from other components that may be present along with Chromium, since viable indigenous bacterial isolates will have developed some degree of resistance to these components. It might be practical to use $\mathrm{Cr}$ (VI) reducing bacteria to reduce other waste metals simultaneously, which shows a positive sign for application of these locally isolated strains in the treatment or detoxification of hexavalent chromium from industrial effluents and Chromium contaminated sites. However, before exploiting the strain as an efficient biotechnological tool for chromium detoxification further investigation needs to be carried out in laboratory scale and in-situ 
metal reduction potential of the Genus has to be assessed.

\section{Acknowledgements}

We would like to acknowledge Orissa Mining Corporation and State Pollution Control Board for giving the permission to conduct the study in Sukinda mining area. We also thank laboratory staff of department of Microbiology, CPGS and Department of Biochemistry, Anatomy, College of Veterinary Science and Animal Husbandry, Orissa University of Agriculture and Technology, Bhubaneswar, Orissa for their co-operation.

\section{References}

Anderson, R.A. 1989. Essentiality of chromium in humans. Sci. Tot. Environ. 86: 75-81.

APHA 1992. Standard methods for the examination of water and wastewater. $18^{\text {th }}$ American Public Health Association, American Water Works Association, Water Environmental Federation. Washington, D.C. 981 p.

Aravindhan, R., K.J. Sreeram, J.R. Rao and B.U. Nair 2007. Biological removal of carcinogenic chromium (VI) using mixed Pseudomonas strains. J. Gener. Appl. Microbiol. 53(2): 7179.

Black Smith Institute Report 2007. The World's worst polluted places A project of Blacksmith Institute. pp. 16-17.

Bryant, T.N. 2004. PIBW in- software for probabilistic identification. J. Appl. Microbiol. 97(6): 1326-1327.

Camargo, F.A., F.M. Bento, B.C. Okeke and W.T. Frankenberger 2003. Chromate reduction by chromium-resistant bacteria isolated from soils contaminated with dichromate. $J$. Environ. Qual. 32: 1228-1233.

Collins, C.H. and P.M. Lyne 1970. Microbiological methods. $6^{\text {th }}$ edn. Butterworth, London. UK.
Faisal, M. and H. Shahida 2004. Microbial conversion of $\mathrm{Cr}$ (VI) in to $\mathrm{Cr}$ (III) in industrial effluents. Afr. J. Biotechnol. 3(11): 610-617.

Flora, S.D., M. Bagnasco, D. Serra and P. Zanacchi 1990. Genotoxicity of chromium compounds, a review. Mutat. Res. 238: 99-172.

Gale, T.F. 1978. Embryonic effect of chromium trioxide in hamsters. Environ. Res. 16: 101109.

Gruber, J.E. and K.W. Jennette 1978. Metabolism of the carcinogenchromate by rat liver microsomes. Biochem. Biophys. Res. Commun. 82: 700-706.

Hansen, H.G. and R. Sorheim 1991. Improved methods for phenotypic characterization of marine bacteria. Microbiol. Methods. 13: 231241.

IARC 1990. Chromium, nickel and welding, monograph on the evaluation of the carcinogenic risk to humans. International Agency for Research on Cancer, Lyon, France. Vol. 49, pp.677.

Kasan, H.C. and A.A.W. Baecker 1989. Activated sludge treatment of coal gasification effluent in a petro-chemical plant-II. Metal accumulation by heterotrophic bacteria. Wat. Sci. Tech. 21(4-5): 297-303.

LATS (Lab-Analytical Technique Series) 2003. Manual on sampling, analysis, characterization of hazardous wastes. Central Pollution Control Board. pp. 66-72.

Losi, M.E. and W.T. Frankenberger 1994. Chromiumresistant microorganisms isolated from evaporation ponds of a metal processing plant. Water Air Soil Pollut. 74: 405-413.

Losi, M.E., C. Amrhein and W.T. Frankenberger 1994. Environmental biochemistry of chromium. Rev. Environ. Contam. Toxicol. 36: $91-121$.

McLean, J. and T.J. Beveridge 2001. Chromate reduction by a Pseudomonad isolated from a site contaminated with chromated copper arsenate. Appl. Environ. Microbiol. 67(3): 1076-1084.

Petrilli, F.L. and S.D. Flora 1977. Toxicity and mutagenicity of hexavalent chromium in 
V. Mishra, D.P. Samantaray, S.K. Dash, B.B. Mishra and R.K. Swain / Our Nature (2010) 8: 63-71

Salmonella typhimurium. Appl. Environ. Microbiol. 33: 805-809.

Rahman, M.U., S. Gul and Z.U. Haq 2007. Reduction of chromium by locally isolated Pseudomonas sp. C-171. Turk. J. Biol. 311: 61-66.

Srinath, T., S. Khare and P.W. Ramteke 2001. Isolation of hexavalent chromium-reducing Cr-tolerant facultative anaerobes from tannery effluent. J. Gener. Appl. Microbiol. 47(6): 307-12.
Verma, S.K. and S.P. Singh 1995. Multiple chemical resistance in the Cynobacterium, Nostoc muscorum. Bull. Environ. Contam. Toxicol. 54: 614-619.

Zakaria, Z.A., Z. Zakaria, S. Surif and W.A. Ahmad 2007. Hexavalent chromium reduction by Acinetobacter haemolyticus isolated from heavy-metal contaminated wastewater. $J$. Hazard. Materials 146(1-2): 30-38.

Zobel, C.E. 1946. Marine microbiology. Chron. Bot. Wathampress, Massachusetts, USA. 